\title{
Perilaku Pembajakan Produk Digital: Cerita Dari Mahasiswa Di Yogyakarta
}

\author{
Aditya Pandu Wicaksono ${ }^{1 *}$; Dekar Urumsah ${ }^{2}$ \\ ${ }^{1,2}$ Fakultas Ekonomi, Universitas Islam Indonesia \\ Korespondensi: aditya.pandu@ uii.ac.id
}

\begin{abstract}
Digital piracy is one of the most famous forms of intellectual property theft and recognized as a criminal act. This research investigates the reason how people prefer to buy pirated product to genuine product. The purpose of the research is to understand how benefit, social, economic, and moral factor influencing digital piracy. The sample is students at one private university in Yogyakarta. Purposive sampling is applied by distributing questionnaires to respondents to be answered voluntarily. This research finds perceived usefulness using pirated product and social factor influencing intention to pirates. In other hand, moral judgment can not be a deterrent tool preventing piracy behavior. People do not seem to be afraid of the consequences of committing digital piracy. Price has been the main issue to motivate people committing digital piracy. Digital product's price is high and being perceived as unfair and unacceptable by low-income people. This research provides some insight to industry and government about the reasons why people pirate digital products. The government needs to strengthen the rules to protect and prevent intellectual property from piracy behavior.
\end{abstract}

Keywords: $\quad$ Piracy behavior, Digital piracy, Theory of Planned Behavior, Technology Acceptance Model

\begin{abstract}
ABSTRAK
Pembajakan produk digital adalah salah satu bentuk popular dari pencurian kekayaan intelektual dan diakui sebagai perilaku kriminal. Penelitian ini dilakukan untuk menginvestigasi alasan mengapa orang membajak daripada membeli produk asli. Tujuan penelitian ini untuk memahami bagaimana faktor manfaat, sosial, ekonomi, dan moral mempengaruhi pembajakan digital. Penelitian ini menggunakan sampel mahasiswa dari satu universitas swasta di Yogyakarta. Purposive sampling diterapkan dan mendistribusi kuesioner ke responden untuk diisi secara sukarela. Penelitian ini menemukan bahwa persepsi manfaat dari produk bajakan dan pengaruh sosial mendorong munculnya niat pembajakan. Di lain pihak, penilaian moral tidak dapat menjadi pencegah untuk menghalangi perilaku pembajakan. Orang tidak takut terhadap konsekuensi dari pembajakan digital. Harga menjadi isu utama yang memotivasi perilaku pembajakan. Harga dari produk digital dianggap tidak adil dan tidak dapat diterima oleh orang dengan pendapatan rendah. Penelitian ini memberikan wawasan kepada perusahan dan pemerintah tentang alasan pembajakan dilakukan. Pemerintah perlu untuk memperkuat aturan-aturan dalam rangka melindungi kekayaan intelektual dan mencegah perilaku pembajakan.
\end{abstract}

Kata Kunci: Perilaku pembajakan, Pembajakan digital, Theory of Planned Behavior, Technology Acceptance Model

DOI : 10.20885/jabis.vol17.iss1.art2

\section{PENDAHULUAN}

Seiring dengan perkembangan teknologi, berbagai produk yang memiliki hak cipta seperti buku, musik, dan film telah berubah ke dalam format digital. Dalam dunia buku misalnya, teknologi menawarkan $e$ book dan alat baca elektronik (tablet dan e-reader) yang merubah pola bagaimana seseorang biasanya membaca (Kumbhar 2012). Secara umum, produk dengan format digital dapat diakses di internet dan secara substansial meningkatkan kesempatan untuk mengunduh (download). Dalam rangka menghargai kekayaan intelektual, seseorang yang ingin mendapatkan produk tersebut harus membeli hak cipta dari 
produk tersebut. Namun demikian, permintaan pada format digital meningkat secara cepat seiring dengan perkembangan teknologi yang pesat. Beberapa penelitian telah memberikan peringatan akan terjadinya peningkatan pembajakan sebagai dampak kemudahan akses dan kemudahan pembagian data (data sharing) (Zimerman 2011; Carmen, Carmen, dan Javier 2014). Jackman dan Torde (2014) berargumen bahwa perkembangan teknologi dan transformasi dari tradisional ke format digital secara tidak langsung telah membuka jalan dalam pencurian kekayaan intelektual. Sudler (2013) memberikan penjelasan bahwa datangnya era digital media dan perkembangan World Wide Web bersamaan dengan meningkatnya kecepatan bandwidth memfasilitasi kegiatan pembajakan dan dapat disebarkan secara internasional. Pengambilan produk bajakan di internet bukanlah sesuatu yang sulit, Cooper dan Harrison (2015) menyimpulkan bahwa proses mengunduh produk bajakan di internet dapat dilakukan hanya kurang dari satu menit.

Envisional (2011) menemukan fakta bahwa kegiatan pembajakan produk digital terjadi secara besar-besaran di dunia. Dilihat dari lalu lintas penggunaan internet, 23,76 persen dari lalu lintas penggunaan internet di dunia pada tahun 2010 digunakan untuk pembajakan, yang merupakan peringkat kedua tujuan penggunaan internet. Di Indonesia, pembajakan kekayaan intelektual baik produk tradisional maupun format digital banyak terjadi dengan kerugian yang mencapai 5 triliun rupiah per bulan (Tribun News 2014). Menurut data yang diterbitkan Business Software Alliances (2010), kerugian akibat pembajakan produk software di Indonesia mencapai US\$886 juta pada tahun 2009. Fakta lain menyebutkan 39\% dari software yang dipasang di komputer bukan produk yang terlisensi resmi. Dari fakta tersebut terdapat bahaya kerugian yang mengintai perusahaan yang menghasilkan produk format digital diakibatkan tidak dapat mengkapitalisasi kesempatan yang seharusnya diperoleh (Carmen, Carmen, dan Javier 2014).

Pertanyaan yang mengemuka adalah apa alasan yang mendasari perilaku pembajakan terhadap produk digital. Penelitian yang berkembang dalam bidang ini telah dilakukan dengan mempertimbangkan perilaku konsumen yang didasarkan pada theory of planned behavior (TPB) untuk menginvestigasi niat untuk melakukan pembajakan (Cronan dan Al-rafee 2008; Phau et al. 2014; Zhang, Smith, dan McDowell 2009). Dalam perkembangannya TPB telah banyak dimodifikasi untuk mampu menjelaskan lebih dalam perilaku pembajakan. Phau dan Liang (2012) mengembangkan model penelitian dengan menambahkan penilaian moral yang didasarkan pada self-control theory. Carmen, Carmen, dan Javier (2014) menambahkan pokok pembahasan terkait dengan harga produk digital yang terlisensi resmi.

Penelitian ini dilakukan untuk menguji faktor fundamental yang mendorong tindakan pembajakan produk digital yang didasarkan kerangka model dalam technology acceptance model (TAM) dan juga TPB. Tujuan dari penelitian ini adalah untuk mengidentifikasi faktor yang berpengaruh terhadap pembajakan produk digital. Penelitian ini merujuk dan melanjutkan pembahasan pada penelitian terdahulu 
yang menekankan pada faktor persepsi kegunaan dan harga (Carmen, Carmen, dan Javier (2014), penilaian moral (Phau et al. 2014), dan subjective norm (Yoon 2011). Penelitian ini menginvestigasi tidak hanya sebatas niat tetapi dilanjutkan hingga ke perilaku nyata (actual behavior). Penelitian ini juga tidak membatasi investigasi pada pembajakan suatu produk tertentu tetapi menyeluruh kepada jenis produk digital yang dibajak.

\section{KERANGKA LITERATUR DAN PENGEMBANGAN HIPOTESIS}

\section{Pembajakan Produk Digital}

Dalam berbagai literatur, terdapat perbedaan dalam menyebutkan istilah pembajakan produk digital seperti digital piracy dan internet piracy. Pada intinya kedua istilah tersebut memiliki definisi yang sama yaitu penggadaan atau mengunduh hak cipta secara illegal atau tanpa izin (Carmen, Carmen, dan Javier 2014; Phau dan Liang 2012). Pembajakan digital mungkin tidak dianggap sebagai masalah oleh pelakunya. Seperti misalnya dalam mengunduh suatu buku atau artikel jurnal elektronik terdapat website yang dikhususkan untuk membajak. Hal ini pun berlaku untuk hak cipta lain seperti musik, film, software, dll. Kemudahan di internet dalam membajak memunculkan perhatian terhadap etika. Sadar atau tidak sadar bahwa perilaku pembajakan merupakan sebuah pelanggaran terhadap suatu hak cipta (Carmen, Carmen, dan Javier 2014).

Perkembangan teknologi yang semakin maju dengan pengguna teknologi dan godaan pasar yang tinggi mendorong perusahaan untuk memproduksi barang dalam format digital. Proses bisnis produk dengan format digital sebagian besar dilakukan melalui internet. Proses bisnis ini bukan tanpa resiko, internet diketahui sebagai suatu lingkungan baru dalam kriminalitas. Perusahaan mungkin menyadari atau tidak bahwa dengan produksi ke dalam format digital terdapat ancaman yang membayangi kelangsungan usahanya tersebut yaitu pembajakan. Ancaman atau bahkan pembajakan telah melanda seluruh jenis produk digital yang menyebabkan kerugian karena tidak memperoleh keuntungan dari penggunaan barang produksinya oleh konsumen. Pembajakan esensinya merupakan perilaku kriminal yang dapat dikenai hukuman penjara sesuai dengan apa yang telah diatur oleh seluruh negara di dunia termasuk Pemerintah Indonesia (baca Undang-Undang Nomor 28 Tahun 2014). Akan tetapi, pembajakan baik di Indonesia maupun di dunia seperti tidak ada akhir. Pembajakan seakan sulit dihentikan karena pembajakan seperti sebuah perilaku pencurian (kriminal) tetapi tidak ditangani seperti sebuah perilaku kriminal pada umumya (Balestrino 2008). Meskipun sebagai perilaku kriminal, mengunduh produk digital bajakan dominan terjadi di seluruh dunia pada banyak pengguna komputer khususnya di usia remaja dan mahasiswa (Arli dan Tjiptono 2016).

Penelitian dari Swinyard, Rinne, dan Keng Kau (1990) menemukan kesimpulan bahwa orang Asia pada umumya lebih menerima menggunakan produk bajakan daripada orang Amerika. Orang-orang 
Asia lebih suka menyalin (copy), membeli produk digital, dan cenderung membiarkan kegiatan pembajakan. Dibandingkan dengan orang barat (western people), orang Asia tidak mempertimbangkan moral apakah pembajakan yang dilakukannya salah atau benar. Orang barat cenderung melihat berdasarkan prinsip benar atau salah tanpa bergantung pada situasi yang melandasi perbuatan tersebut. Melihat fakta di Indonesia, perilaku pembajakan sangat banyak terjadi dan orang Indonesia cenderung menggunakan produk bajakan sebagai produk substitusi produk digital yang terlisensi. Biasanya, pembajakan produk digital terjadi pada negara dengan pendapatan rata-rata rendah dengan jumah pengangguran tinggi (Arli dan Tjiptono 2016). Secara spesifik pada tahun 2015, nilai peredaran dalam produk pembajakan perangkat lunak (software) di Indonesia mencapai 14,4 triliun dengan persentase $84 \%$ dari jumlah perangkat lunak yang beredar (Kompas 2016).

Adopsi dari internet yang saat ini sangat mudah diterima oleh masyarakat telah membuka peluang baru dalam berbagi informasi termasuk file sharing yang mendorong individu untuk menikmati produk bajakan (Chalkiti dan Sigala 2008; Altschuller dan Benbunan-Fich 2009). Hal ini diperkuat dengan adanya koneksi internet yang cepat dan murahnya storage online memfasilitasi untuk terjadinya pembajakan produk digital (Smith dan Telang 2010). Oleh karena itu, perilaku pembajakan merupakan suatu perilaku yang mudah untuk dilakukan dan tidak ada orang yang tersakiti secara fisik.

\section{Technology Acceptance Model}

Vasileiou, Hartley, dan Rowley (2009) merekomendasikan penelitian di area adopsi dan penggunaan teknologi harus mempertimbangkan menggunakan teori-teori penerimaan teknologi. Oleh karena itu technology acceptance model (TAM) merupakan kerangka yang tepat untuk menjelaskan dampak penggunaan teknologi termasuk pembajakan (Carmen, Carmen, dan Javier 2014). TAM merupakan kerangka model dasar yang digunakan untuk mengetahui penerimaan terhadap suatu teknologi. TAM muncul dari penelitian yang dilakukan Davis, Bagozzi, dan Warshaw 1989) yang mengadopsi theory of reasoned action (TRA) (Fishbein dan Ajzen 1975) (saat ini berkembang menjadi TPB) yang merupakan model untuk mengetahui faktor pendorong berperilaku. TAM menggunakan TRA karena model dalam TRA dapat digunakan untuk menjelaskan perilaku dalam teknologi. Akan tetapi, TAM kurang dapat diterapkan secara luas daripada TRA yang dapat diterapkan diseluruh jenis perilaku, TAM hanya terbatas di area perilaku teknologi. TAM mengasumsikan persepsi kemudahaan dan kemanfaatan sebagai dampak utama terhadap perilaku individu untuk berniat menggunakan teknologi hingga menggunakan teknologi yang nyata. Selanjutnya, persepsi kemanfaatan teknologi tergantung dengan adanya persepsi kemudahaan menggunakan teknologi. TAM kemudian dikembangkan dengan menambahkan eksternal variabel yang lebih spesifik untuk menjelaskan persepsi kemudahan dan kemanfaatan terhadap penggunaan teknologi (Venkatesh 2000; Venkatesh dan Bala 2008). 


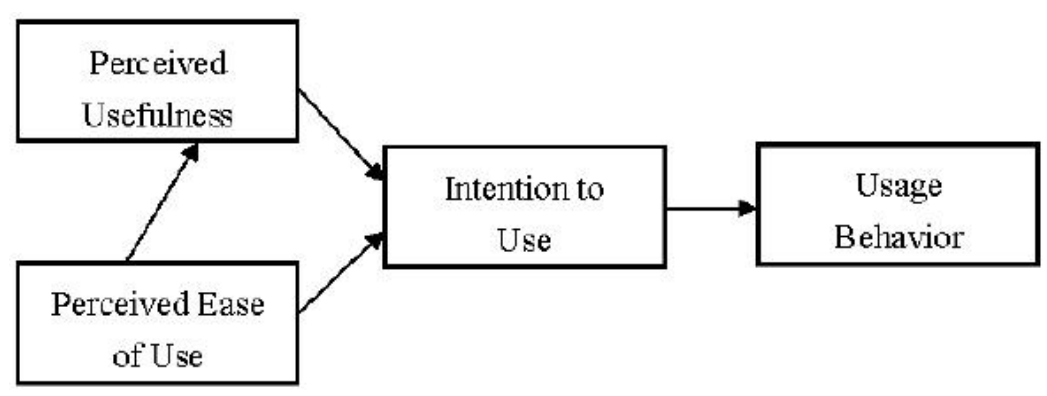

Gambar 1. Technology Acceptance Model (Davis, Bagozzi, dan Warshaw 1989)

\section{Persepsi Manfaat (Perceived Usefulness)}

Motivasi untuk menggunakan teknologi didasari adanya persepsi bahwa teknologi memiliki manfaat terutama untuk meningkatkan performa (Venkatesh dan Bala 2008). Motivasi menggunakan teknologi berdasarkan manfaat merupakan bentuk motivasi ekstrinsik dari individu. Motivasi ekstrinsik merujuk pada aktivitas dimana terdapat persepsi bahwa aktivitas yang dilakukan dipersepsikan sebuah instrument untuk memperoleh keluaran (outcome) tertentu seperti performa kerja, kenaikan gaji, dan promosi (Davis 1989). Persepsi kemanfaatan yang ada didalam TAM adalah salah satu bagian dari kerangka motivasi ekstrinsik. Davis, Bagozzi, dan Warshaw (1989) mendefinisikan persepsi kemanfaatan sebagai derajat yang mana seseorang percaya bahwa menggunakan teknologi akan meningkatkan performa kerjanya. Individu yang akan menggunakan teknologi akan termotivasi jika dengan teknologi tersebut memberikan dampak positif untuk dirinya.

Jika dikaitkan dengan perilaku pada pembajakan produk digital, produk bajakan memiliki fitur atau bentuk yang sama dengan aslinya. Sebagai contoh di Indonesia, sebuah software bajakan untuk komputer memiliki fungsi dan kegunaan yang sama dengan biaya yang lebih murah bahkan sama gratis. Fenomena ini juga terjadi pada produk digital lain seperti buku, musik, film, dan permainan. Artinya, dengan adanya produk bajakan tersebut individu akan merasa bahwa produk bajakan mampu menggantikan peran dari produk aslinya. Sebagai bukti, 39\% software yang terpasang di komputer bukan produk yang asli dan 95\% DVD film yang dijual di pasar Indonesia adalah bajakan (McGuire 2009). Hal ini memunculkan opini bahwa mengapa harus membeli produk digital yang asli dengan harga yang tinggi kalau dapat memiliki produk bajakan dengan fitur dan manfaat yang sama dengan aslinya. Dengan demikian muncul persepsi bahwa dengan menggunakan produk bajakan performa dari individu akan tetap sama, sehingga niat untuk membajak akan muncul dengan dikaitkan motivasi memperoleh manfaat yang sama dari produk bajakan.

\section{H1. Persepsi kemanfaatan berpengaruh positif terhadap niat pembajakan}

\section{Norma Subjektif (Subjective Norm)}


Sebagian besar individu yang melakukan pembajakan produk digital tidak mengetahui bahwa perilaku tersebut ilegal (Morris dan Higgins 2010). Namun demikian penelitian menyebutkan bahwa pelaku tidak memandang perilaku pembajakan adalah sebuah perilaku negatif (Hinduja 2007). Individu atau konsumen percaya bahwa pembajakan digital adalah kejahatan tanpa korban dimana kreator dianggap sudah mendapatkan kompensasi yang memadai (Lysonski dan Durvasula 2008). Terdapat justifikasi dan kepercayaan dari pelaku pembajakan bahwa perilakunya bukanlah sebuah kriminal dan dilakukan oleh orang banyak di lingkungannya. Lingkungan berperan aktif dalam menyebarkan produk bajakan ke konsumen dengan menawarkan benefit yang sama dengan produk aslinya (Yoon 2011). Perilaku demikian dapat dijelaskan melalui neutralization theory dimana seseorang dapat merasionalisasikan dan menjustifikasi perilaku yang menyimpang dianggap ke dalam perilaku yang "normal" (Chatzidakis et al. 2004). Perilaku pembajakan produk digital sangat mungkin terjadi karena seseorang dapat mencari justifikasi dan rasionalisasi sebelum melakukan pembajakan (Phau et al. 2014). Kurangnya korban yang terlihat maupun respon dari masyarakat dan pemerintah mengakibatkan pembajakan lebih mudah untuk dilakukan dengan justifikasi tertentu (Morris and Higgins 2010).

Subjective norms merupakan konstruk yang terdapat dalam TPB untuk mempengaruhi seseorang dalam berperilaku. Ajzen (1991) mendefinisikan subjective norm sebagai sebuah tekanan sosial yang diterima individu untuk melakukan atau tidak melakukan suatu perilaku. Dalam penelitian ini subjective norm dipresentasikan sebagai faktor sosial yang memberikan pengaruh melalui teman, kolega, dan juga keluarga untuk mempengaruhi seseorang melakukan pembajakan. Telah ditemukan bukti bahwa pengaruh dari lingkungan dapat mendorong seseorang untuk melakukan pembajakan (Phau et al. 2014). Dengan adanya pengaruh dari lingkungan dengan mempertimbangkan neutralization theory mampu untuk membantu mengilustrasikan mengapa seseorang melakukan pembajakan. Bearden, Netemeyer, dan Teel (1989) menemukan bahwa individu sangat mudah terkena pengaruh interpersonal yang kemungkinan akan mengikuti norma perilaku dari rekannya. Sehingga, banyak individu yang menggunakan justifikasi bahwa perilaku pembajakan telah dilakukan oleh banyak orang dan dianggap sebagai sesuatu yang tidak melanggar norma. Dengan subjective norm telah terbukti dapat mempengaruhi seseorang untuk memiliki niat melakukan pembajakan (Yoon 2011).

\section{H2. Subjective norm berpengaruh positif terhadap niat pembajakan}

\section{Penilaian Moral (Moral Judgment)}

Dalam penelitian di bidang pembajakan digital, telah dilibatkan variabel moral untuk menginvestigasi perilaku pembajakan digital (Higgins 2007; Phau et al. 2014). Dengan adanya investigasi moral, penelitian akan semakin dalam menjelaskan perilaku pembajakan apakah melibatkan penalaran moral atau tidak. Cronan dan Al-rafee (2008) dalam penelitiannya menggunakan penilaian moral yang diartikan sebagai 
perasaan bersalah atau kewajiban pribadi untuk melakukan atau tidak melakukan perilaku. Penelitian ini menggunakan penilaian moral sebagai faktor untuk menginvestigasi munculnya niatan untuk melakukan pembajakan produk digital. Penilaian moral didefinisikan cara seseorang beralasan ketika dihadapkan dengan dilema etika. Penilaian moral akan dihubungkan dengan perilaku untuk memperluas penilain moral dari seseorang sebagai cara yang berbeda untuk menafsirkan situasi (Banerjee et al. 1998).

Pembajakan digital merupakan bagian dari perilaku mencuri yang saat ini masih dianggap "normal". Akan tetapi, jika individu melihat pembajakan merupakan perilaku yang salah, terdapat kecenderungan seseirang untuk mengendalikan perbuatan pembajakan. Dengan demikian, seseorang akan dihadapkan pada sebuah dilema apakah perilakunya tersebut akan mendatangkan keuntungan atau kerugian bagi orang lain. Dalam pembajakan digital, walaupun saat ini masih dianggap "normal", pembajakan yang terjadi tanpa disadari telah merusak norma dan mengakibatkan kerugian bagi para kreator akibat kehilangan kesempatan untuk mengkapitalisasi penjualan atas produknya. Artinya ada permasalahan moral dari para pelaku pembajakan sehingga perilaku pembajakan tetap dilakukan.

Penelitian dari Swinyard et al. (1990) menjelaskan perbedaan penggunaan moral antara orang Asia dan Amerika. Penelitian tersebut menjelaskan bahwa orang Amerika lebih taat kepada aturan dan norma dengan berdasarkan benar dan salah sehingga akan memeriksa situasi dan lebih berhati-hati terhadap manfaat yang dihasilkan dari pelanggaran hak cipta. Sedangkan orang Asia kurang memperhatikan moral dan lebih berdasar pada konsekuensi manfaat perbuatan yang dilakukan. Khususnya di Indonesia, Arli dan Tjiptono (2016) menemukan konsumen di Indonesia khususnya mahasiswa tidak takut terhadap konsuekensi atas legal yang telah dilanggar. Lebih lanjut Phau et al. (2014) menemukan terdapat hubungan negatif antara penilaian moral dengan niat melakukan pembajakan. Dengan demikian penilaian moral yang rendah dari individu akan memicu niatan untuk melakukan pembajakan produk digital.

\section{H3. Penilaian moral berpengaruh negatif terhadap niat pembajakan}

\section{Penerimaan Harga (Price Acceptance)}

Penelitian ini melibatkan aspek finansial yang dibangun ke dalam model penelitian sebagai variabel penerimaan harga. Penerimaan harga menjelaskan persepsi konsumen dari area bisnis yang bertujuan untuk mendatangkan profit. Dalam arti luas, harga merupakan biaya atau pengorbanan yang diserahkan dalam kegiatan pertukaran untuk mendapatkan produk atau layanan. Baya tersebut berasal dari biaya moneter (seperti harga) dan non moneter (seperti waktu) yang merupakan persepsi dari konsumen untuk memilih tempat yang sesuai (Mccorkle et al. 2012). Dalam hal produk digital, harga yang ditentukan untuk satu produk digital tidak terjangkau oleh konsumen. Harga dari suatu produk digital yang mahal dipersepsikan tidak adil, tidak dapat diterima, dan berpotensi untuk memunculkan perilaku pembajakan 
(Carmen et al. 2014). Harga harus dipertimbangkan sebagai determinan kunci untuk konsumen apakah membeli atau membajak untuk mendapatkan suatu produk digital. Semakin tinggi harga yang diberikan maka akan meningkatkan keinginan untuk melakukan pembajakan. Pembajakan akan lebih besar jika konsumen tidak ingin mengorbankan hartanya untuk membeli produk digital yang asli (Jackman dan Torde 2014).

Penelitian dari Lau (2006) dengan metode kualitatif telah menjelaskan bagaimana peran harga dalam perilaku pembajakan software. Penelitian tersebut menemukan indikasi bahwa individu akan cenderung mengurangi pembajakan apabila harga software diturunkan dengan jumlah yang besar. Selain itu terdapat upaya dari perusahaan untuk melakukan upaya marketing dengan memberikan potongan harga jika membeli dalam jumlah besar. Seperti yang diucapkan oleh responden Lau (2006 hal. 412) berikut ini.

Perusahaan software selalu berkata jika individu membeli software legal dengan jumlah lebih banyak, mereka akan memberikan harga yang lebih murah. Tetapi, mengapa tidak memberikan harga yang murah untuk menarik orang membeli produk mereka terlebih dulu?.

Praktik marketing tersebut memang sulit diterima oleh konsumen karena memang harga yang sangat mahal untuk setiap produknya. Dampaknya, individu lebih tertarik untuk menggunakan yang bajakan dengan biaya yang lebih murah. Isu mengenai harga bukanlah sesuatu yang sederhana karena sebuah produk bajakan dengan aslinya sangat sulit dibedakan karena produk digital berbeda dengan barang berwujud lainnya. Harga menjadi sesuatu yang menentukan ketika harga yang ditawarkan tinggi maka pembajakan juga akan tinggi, juga sebaliknya (Lau 2006). Carmen, Carmen, dan Javier (2014) menemukan bahwa ketika penerimaan atas harga dari konsumen baik, maka niat untuk melakukan pembajakan akan rendah.

\section{H4. Penerimaan harga berpengaruh negatif terhadap niat pembajakan}

\section{Niat (Intention)}

Niat adalah sebuah indikator yang mana seseorang berkeinginan untuk mencoba dan seberapa banyak usaha yang dikeluarkan untuk memunculkan suatu perilaku. Niat merupakan prediktor yang tepat untuk memprediksi perilaku. Dalam teori TPB (Ajzen 1991) dan TAM (Davis, Bagozzi, dan Warshaw 1989), niat dihipotesiskan langsung terhadap perilaku yang nyata (actual behavior). Kedua teori tersebut telah membuktikan bahwa dengan adanya niat maka perilaku akan diteruskan menjadi perilaku yang nyata. Oleh karena itu, penelitian ini juga menghipotesakan niat untuk membajak menjadi prediktor untuk perilaku membajak yang nyata.

\section{H5. Niat membajak berpengaruh positif terhadap perilaku pembajakan}




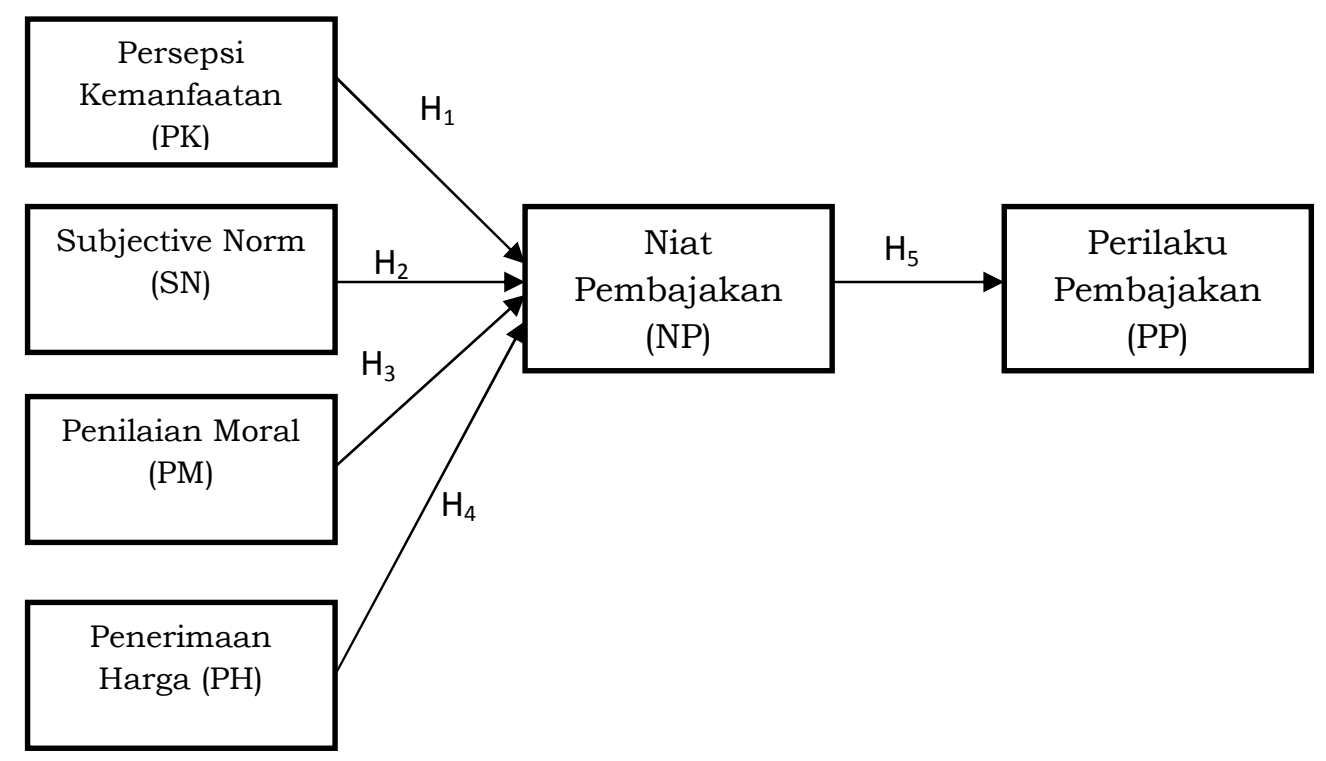

Gambar 2. Model Penelitian

\section{METODOLOGI PENELITIAN}

\section{Pengumpulan Data dan Sampel}

Penelitian ini mengambil sampel dari mahasiswa. Alasan yang mendasari pemilihan mahasiswa sebagai sampel karena remaja terutama mahasiswa merupakan pengguna terbesar dari produk bajakan (Phau dan Liang 2012; Yoon 2011). Arli dan Tjiptono (2016) menyebutkan bahwa pembajakan digital lebih umum dilakukan di dunia akademis daripada dunia bisnis. Universitas diyakini sebagai tempat banyak terjadinya proses mengunduh material digital. Penggunaan mahasiswa sebagai sampel telah dilakukan oleh berbagai penelitian yang telah mampu menjelaskan dengan baik faktor pendorong pembajakan digital dari berbagai perspektif (Arli dan Tjiptono 2016; Phau dan Liang 2012).

Penelitian ini menggunakan pendekatan kuantitatif dengan menerapakan purposive sampling sebagai teknik pengumpulan data. Adapun kriteria yang harus dipenuhi sebagai responden adalah mahasiswa yang memiliki keahlian penggunaan internet dan setidaknya pernah melakukan perilaku pembajakan digital (mengunduh dari internet). Penelitian ini menggunakan kuesioner elektronik dengan bantuan google form yang telah diisi oleh 216 mahasiswa strata-1 di satu perguruan tinggi swasta di Yogyakarta. Kuesioner yang tidak lengkap tidak diikutsertakan ke dalam perhitungan sehingga terdapat 209 kuesioner yang terisi lengkap dan dapat diolah. Profil demografi dari responden adalah sebagai berikut: 62 persen adalah perempuan dan 38 persen adalah laki-laki. Demografi dari responden lebih lengkap disajikan di tabel 1 . 


\section{Pengukuran}

Penelitian ini menggunakan item pertanyaan yang telah tervalidasi dari penelitian sebelumnya untuk digunakan dalam investigasi penelitian ini. Masing-masing item berisi enam poin skala likert dari 1 (sangat tidak setuju) hingga 6 (sangat setuju). Persepsi manfaat diukur dengan menggunakan 5 item diadopsi dari Carmen, Carmen, dan Javier (2014) dan Yoon (2011). Subjective norm diukur dengan 4 item yang diambil dari Venkatesh dan Bala (2008); Ajzen (1991); dan Yoon (2011) yang disesuakan ke konteks pembajakan digital. Penilaian moral diukur dengan 5 item yang diadopsi dari Tan (2002) dan Yoon (2011). Penerimaan harga diukur dengan 5 item yang diambil dari Carmen, Carmen, dan Javier (2014). Niat untuk membajak diukur dengan 4 item dari Carmen, Carmen, dan Javier (2014) dan Taylor (2012). Sedangkan untuk perilaku pembajakan diukur dengan 4 item yang diambil dari Cronan dan Alrafee (2008). Tabel 2 menyajikan seluruh item yang digunakan dalam penelitian ini.

Tabel 1. Demografi Responden

\begin{tabular}{|c|c|c|}
\hline Kategori & Frekuensi & $\%$ \\
\hline \multicolumn{3}{|l|}{ Gender } \\
\hline Laki-Laki & 79 & 38 \\
\hline Perempuan & 130 & 62 \\
\hline \multicolumn{3}{|l|}{ Umur } \\
\hline 17-20 tahun & 163 & 78 \\
\hline 21-24 tahun & 45 & 21 \\
\hline$>24$ tahun & 1 & 1 \\
\hline \multicolumn{3}{|l|}{ Pemakaian Internet per Bulan } \\
\hline$<3$ Gigabytes & 14 & 7 \\
\hline 3-7 Gigabytes & 109 & 52 \\
\hline$>7$ Gigabytes & 86 & 41 \\
\hline
\end{tabular}

\section{HASIL PENELITIAN DAN PEMBAHASAN}

\section{Hasil Statistik}

Perhitungan statistik menggunakan SmartPLS 2.0 untuk menghitung data yang dapat diolah. Pembahasan hasil statistic terdiri dari dua model yaitu model pengukuran (outer model) dan model struktural (inner model). Model pengukuran terdiri dari pengujian validitas (convergent dan discriminant validity) dan reliabilitas yang ditunjukan dengan nilai composite reliability. Untuk memenuhi convergent validity, nilai dari outer loading masing-masing item lebih dari 0.5 untuk dapat diterima. Selain itu, nilai average variance extracted (AVE) setiap variabel harus lebih besar dari 0,5 (Gefen, Straub, and Boudreau 2000). Nilai loading dari item kurang dari 0,5 harus dihapus karena akan menurunkan nilai AVE variabel. Sedangkan untuk discriminant validity menggunakan akar pangkat dua dari AVE variabel. Nilai akar 
pangkat dua dari variabel harus lebih besar daripada korelasinya dengan variabel lain (Fornell dan Larcker 1981). Untuk membentuk reliabilitas, nilai dari composite reliability (CR) setidaknya memiliki nilai 0,6 tetapi akan lebih baik jika bernilai 0,7 (Hair et al. 2010).

Dari hasil perhitungan statistik, ditemukan satu item dalam variabel niat untuk membajak (NP3) dan satu item dari penilaian moral (PM5) memiliki loading di bawah 0,5 sehingga harus dikeluarkan dari perhitungan. Perhitungan ulang dilakukan dengan hasil tidak ada item di bawah 0,5 dengan interval loadings 0,5596 hingga 0,9303. Sedangkan nilai AVE dari seluruh variabel melebihi 0,5 dengan interval 0,5297 hingga 0,7648. Dengan demikian convergent validity telah terpenuhi. Discriminant validity telah terpenuhi dengan bukti nilai akar pangkat dua AVE lebih besar daripada korelasi variabel itu sendiri dengan variabel lainnya. Selain itu, pengujian reliabilitas telah terpenuhi dengan interval nilai composite reliability (CR) 0,8167 hingga 0,9419. Pengujian dari convergent validity, discriminant validity, dan reliabilitas tersaji dalam tabel 3 dan tabel 4.

Pengujian struktural menggunakan bootsraping method yang digunakan untuk menguji signifikasi hubungan atau hipotesa yang dibangun dalam model penelitian (Gambar 1) (Beaumont dan Bocci 2009) . Bootstraping menghasilkan perkiraan yang lebih baik dengan sampel yang kecil. Penelitian ini merupakan uji dua sisi (two-tailed test) dengan nilai kritis (critical value) adalah 1,65 (level signifikansi 10\%), 1,96 (level signifikansi 5\%), dan 2,58 (level signifikansi 1\%) (Hair, Ringle, dan Sarstedt 2011). Hubungan dikatakan signifikan jika t-value lebih dari level signifikansinya. Selain itu, pengujian struktural menyajikan koefisien determinasi ( $r$ square) yang berguna untuk menjelaskan kekuatan variabel independen dalam menjelaskan variabel dependen. Hasil pengujian koefisien determinasi dari variabel persepsi manfaaat, subjective norm, penilaian moral, dan penerimaan harga mampu menjelaskan $44,30 \%$ dari niat melakukan pembajakan. Sedangkan niat melakukan pembajakan mampu menjelaskan $24,87 \%$ dari perilaku nyata pembajakan.

Pengujian hipotesis yang disajikan dalam tabel 5 menemukan bahwa seluruh hipotesa yang diajukan didukung dengan pengaruh yang signifikan. $\mathrm{H}_{1}$ menduga bahwa persepsi manfaat dari produk bajakan berpengaruh positif terhadap niat pembajakan. Hasil menunjukan bahwa hubungan persepsi manfaat dan niat pembajakan adalah positif dan signifikan $(\beta=0,3368 t=8,1808)$. 
Tabel 2. Pengukuran Skala Item

\begin{tabular}{|c|c|c|}
\hline Skala & Interval skala & Referensi \\
\hline \multicolumn{3}{|l|}{ 1. Persepsi Manfaat } \\
\hline \multicolumn{3}{|l|}{ 1.Menggunakan produk bajakan bermanfaat } \\
\hline \multicolumn{3}{|l|}{ 2.Produk bajakan meningkatkan performa } \\
\hline \multicolumn{3}{|l|}{ 3.Produk bajakan meningkatkan produktivitas } \\
\hline $\begin{array}{l}\text { 4.Lebih efektif menggunakan produk bajakan } \\
\text { daripada aslinya }\end{array}$ & 6 (sangat setuju) & $\begin{array}{l}\text { Javier (2014); Yoon } \\
\qquad(2011)\end{array}$ \\
\hline \multicolumn{3}{|l|}{ 5.Manfaat produk bajakan sama dengan aslinya } \\
\hline \multicolumn{3}{|l|}{ 2. Subjective Norm } \\
\hline \multicolumn{3}{|l|}{ 1.Orang disekitar saya menggunakan produk bajakan } \\
\hline $\begin{array}{l}\text { 2.Membajak bukan hal yang salah menurut teman } \\
\text { 3.Saya mengikuti teman untuk menggunakan produk } \\
\text { bajakan }\end{array}$ & $\begin{array}{l}1 \text { (sangat tidak setuju) hingga } \\
6 \text { (sangat setuju) }\end{array}$ & $\begin{array}{l}\text { Venkatesh dan Bala } \\
\text { (2008); Ajzen (1991); } \\
\text { Yoon (2011) }\end{array}$ \\
\hline \multicolumn{3}{|l|}{ 4.Teman mempengaruhi saya untuk menggunakan } \\
\hline \multicolumn{3}{|l|}{ 3. Penilaian Moral } \\
\hline \multicolumn{3}{|l|}{ 1.Menggunakan produk bajakan adalah benar } \\
\hline \multicolumn{3}{|l|}{ 2.Membajak tidak merusak moral } \\
\hline 3.Saya tidak bersalah jika membajak & 1 (sangat tidak setuju) hingga & Tan (2002) · Yoon (2011) \\
\hline \multicolumn{3}{|l|}{ 4.Pembajan adalah perilaku yang dibenarkan } \\
\hline \multicolumn{3}{|l|}{$\begin{array}{l}\text { 5.Saya memikirkan moral ketika menggunakan } \\
\text { produk bajakan }\end{array}$} \\
\hline \multicolumn{3}{|l|}{ 4. Penerimaan Harga } \\
\hline \multicolumn{3}{|l|}{ 1.Harga produk asli bukan masalah } \\
\hline \multicolumn{3}{|l|}{ 2.Produk asli masih dianggap wajar } \\
\hline 3.Saya menerima harga produk asli & 1 (sangat tidak setuju) hingga & Carmen, Carmen, dan \\
\hline \multicolumn{3}{|l|}{ 4.Saya akan membayar berapapun harga produk asli } \\
\hline \multicolumn{3}{|l|}{ 5. Saya akan membeli daripada membajak } \\
\hline \multicolumn{3}{|l|}{ 5. Niat } \\
\hline \multicolumn{3}{|l|}{ 1.Saya akan mengambil produk bajakan } \\
\hline \multirow{3}{*}{$\begin{array}{l}\text { 2.Jika ada kesempatan saya akan membajak } \\
\text { 3.Saya tidak pernah ingin mengambil bajakan } \\
\text { 4.Jika mendapatkan akses, saya akan mengambil } \\
\text { produk bajakan }\end{array}$} & & Carmen, Carmen, dan \\
\hline & 1 (sangat tidak setuju) ningga & Javier (2014); Taylor \\
\hline & & (2012) \\
\hline \multicolumn{3}{|l|}{ 6. Perilaku Pembajakan } \\
\hline \multicolumn{3}{|l|}{ 1.Seberapa sering mengambil produk bajakan } \\
\hline 2.Saya menggunakan produk bajakan & 1 (tidak pernah) hingga 6 & Cronan dan Al-rafee \\
\hline 3.Seberapa banyak produk bajakan yang diunduh & 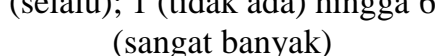 & $(2008)$ \\
\hline 4.Saya beralih dari asli ke bajakan & & \\
\hline
\end{tabular}


Tabel 3. Discriminant Validity

\begin{tabular}{lcccccc}
\hline \multicolumn{1}{c}{ Variabel } & NP & MJ & PA & PB & PU & SN \\
\hline NP & $\mathbf{0 , 7 7 5 2}$ & & & & & \\
MJ & 0,3513 & $\mathbf{0 , 8 5 2 9}$ & & & & \\
PA & $-0,1654$ & 0,0323 & $\mathbf{0 , 7 4 6 0}$ & & & \\
PB & 0,5015 & 0,1888 & $-0,2555$ & $\mathbf{0 , 8 5 5 9}$ & & \\
PU & 0,6197 & 0,2792 & $-0,1926$ & 0,4941 & $\mathbf{0 , 8 7 4 5}$ & \\
SN & 0,4832 & 0,2262 & 0,0526 & 0,3210 & 0,6099 & $\mathbf{0 , 7 2 7 8}$ \\
\hline
\end{tabular}

Catatan: Angka diagonal dicetak tebal adalah $\sqrt{\mathrm{AVE}}$

$\mathrm{H}_{2}$ mengajukan dugaan bahwa subjective norm mempengaruhi secara positif terhadap niat pembajakan. Hasil menemukan bahwa terdapat hubungan positif dan signifikan antara subjective norm dengan niat pembajakan $(\beta=0,1017 t=3,1504) . \mathrm{H}_{3}$ merumuskan dugaan bahwa penilaian moral berpengaruh negatif terhadap niat pembajakan. Hasil menunjukan perbedaan antara hipotesis yang diajukan dengan hasil. Hasil menunjukan terdapat pengaruh positif dan signifikan hubungan penilaian moral dengan niat pembajakan $(\beta=0,2527 t=8,4572)$.

$\mathrm{H}_{4}$ mengajukan dugaan bahwa penerimaan harga berpengaruh negatif terhadap niat untuk membajak dan $\mathrm{H}_{5}$ menduga bahwa niat pembajakan berpengaruh positif terhadap perilaku nyata pembajakan. Hasil menunjukan bahwa penerimaan harga berpengaruh negatif dan signifikan terhadap niat membajak ( $\beta=-0,1179 t=2,3201)$, sedangkan niat membajak berpengaruh positif dan signifikan terhadap perilaku nyata pembajakan $(\beta=0,5015 t=18,4296)$.

\section{Pembahasan}

Penelitian ini menggunakan teori TAM dan TPB sebagai acuan untuk membangun model penelitian yang diinvestigasi dalam penelitian ini. Penelitian ini memandang bahwa perubahan dan perkembangan teknologi yang semakin pesat memberikan kemudahan untuk penggunanya. Pengguna smartphone misalnya, memiliki ekspektasi bahwa dengan menggunakan alat tersebut akan membantu dan mempermudah aktivitas hariannya khususnya bagi mahasiswa. Pola seperti ini dianggap sebagai lahan baru untuk berbagai jenis perusahaan yang menyediakan hak intelektual (seperti musik, buku, software, dll) untuk memperoleh profit di area yang lain. 
Tabel 4. Convergent Validity dan Reliabilitas

\begin{tabular}{|c|c|c|c|}
\hline Kode & Loading & AVE & CR \\
\hline Persepsi Manfaat & & \multirow{6}{*}{0,7648} & \multirow{6}{*}{0,9419} \\
\hline PM1 & 0,8922 & & \\
\hline PM2 & 0,9207 & & \\
\hline PM3 & 0,8921 & & \\
\hline PM4 & 0,8502 & & \\
\hline PM5 & 0,8133 & & \\
\hline \multicolumn{4}{|c|}{ Subjective Norm (SN) } \\
\hline SN1 & 0,6086 & \multirow{4}{*}{0,5297} & \multirow{4}{*}{0,8167} \\
\hline $\mathrm{SN} 2$ & 0,7201 & & \\
\hline SN3 & 0,8195 & & \\
\hline SN4 & 0,7472 & & \\
\hline \multicolumn{4}{|c|}{ Penilaian Moral (PM) } \\
\hline PM1 & 0,8619 & \multirow{4}{*}{0,7274} & \multirow{4}{*}{0,9143} \\
\hline PM2 & 0,8656 & & \\
\hline PM3 & 0,8671 & & \\
\hline PM4 & 0,8159 & & \\
\hline \multicolumn{4}{|c|}{ Penerimaan Harga $(\mathrm{PH})$} \\
\hline PH1 & 0,7368 & \multirow{5}{*}{0,5565} & \multirow{5}{*}{0,8584} \\
\hline $\mathrm{PH} 2$ & 0,5596 & & \\
\hline PH3 & 0,6127 & & \\
\hline PH4 & 0,8279 & & \\
\hline PH5 & 0,8159 & & \\
\hline \multicolumn{4}{|l|}{$\operatorname{Niat}(N P)$} \\
\hline NP1 & 0,8801 & \multirow{3}{*}{0,6009} & \multirow{3}{*}{0,815} \\
\hline NP2 & 0,6110 & & \\
\hline NP4 & 0,8092 & & \\
\hline \multicolumn{4}{|c|}{ Perilaku Pembajakan (PP) } \\
\hline PP1 & 0,8893 & \multirow{4}{*}{0,7326} & \multirow{4}{*}{0,9163} \\
\hline PP2 & 0,8759 & & \\
\hline PP3 & 0,8437 & & \\
\hline PP4 & 0,8126 & & \\
\hline
\end{tabular}

Untuk memperoleh suatu produk digital, konsumen harus membeli dengan harga tertentu yang kemudian dapat diunduh untuk masuk ke gadget atau smartphone konsumen. Dampaknya, akan ada upaya dari pihak tertentu untuk meretas (hack) produk digital berbayar untuk dapat dimiliki secara gratis. Saat ini sudah sangat umum bahwa setiap individu memiliki kemampuan untuk mengunduh dan memasang 
produk digital ke dalam gadget atau smartphone dan juga tidak asing dengan internet. Demografi responden penelitian ini menemukan bahwa setiap mahasiswa memiliki akses internet pribadi baik di rumah maupun di rumah sewa. Saat ini internet seperti sebuah kebutuhan primer yang wajib untuk menunjang aktivitas seperti unduh dan unggah material digital, berkomunikasi, dan mencari materi pembelajaran. Artinya, sangat mungkin sekali setiap individu mampu untuk mengunduh dan mengunggah material digital bajakan di internet dan membagikannya ke orang lain.

Tabel 5. Hasil Penelitian

\begin{tabular}{lcccc}
\hline Hipotesis & Jalur & Path coefficient & t-value & Hasil \\
\hline $\mathrm{H}_{1}(+)$ & $\mathrm{PU} \rightarrow \mathrm{NP}$ & 0,3368 & 8,1808 & Didukung \\
$\mathrm{H}_{2}(+)$ & $\mathrm{SN} \rightarrow \mathrm{NP}$ & 0,1017 & 3,1504 & Didukung \\
$\mathrm{H}_{3}(-)$ & $\mathrm{PM} \rightarrow \mathrm{NP}$ & 0,2527 & 8,4572 & Tidak Didukung \\
$\mathrm{H}_{4}(-)$ & $\mathrm{PH} \rightarrow \mathrm{NP}$ & $-0,1179$ & 2,3201 & Didukung \\
$\mathrm{H}_{5}(-)$ & $\mathrm{NP} \rightarrow \mathrm{PP}$ & 0,5015 & 18,4296 & Didukung \\
\hline
\end{tabular}

Catatan : signifikansi $0.05(\mathrm{t}>1,96)$

Produk digital bajakan yang beredar saat ini memiliki kualitas yang sama dengan kualitas produk aslinya. Sangat sulit untuk membedakan perbedaan antara produk asli dan bajakan. Dengan demikian terdapat kemungkinan manfaat yang diperoleh jika menggunakan produk digital bajakan akan sama dengan manfaat dari produk aslinya. Dibuktikan oleh hasil penelitian ini yang menjelaskan persepsi manfaat dari produk bajakan akan mendorong untuk memunculkan niat dalam membajak. Arli dan Tjiptono (2016) menemukan bahwa adanya persepsi manfaat yang diperoleh dari produk bajakan akan meningkatkan upaya untuk melakukan pembajakan. Sesuai dengan apa yang dijelaskan dalam ekstrinsik motivasi terhadap teknologi (Davis, Bagozzi, dan Warshaw 1992) bahwa seseorang menggunakan teknologi jika terdapat outcome yang akan diterima. Di area pembajakan produk digital, individu akan melakukan pembajakan jika terdapat manfaat yang diperoleh. Dengan kualitas dan manfaat produk bajakan yang sama dengan aslinya maka pembajakan akan dilakukan dengan biaya dan pengorbanan yang lebih sedikit.

Pengaruh dari sosial (seperti lingkungan, teman, dan keluarga) telah menjadi pendorong dalam memunculkan niat untuk berperilaku seperti yang dijelaskan dalam TPB dan TAM. Pengaruh sosial tersebut juga menjadi pengaruh dari perilaku pembajakan. Penelitian ini menemukan bahwa individu yang memperoleh pengaruh sosial cenderung untuk melakukan pembajakan. Individu yang dengan mudah dipengaruhi oleh pengaruh sosial termotivasi untuk melakukan pembajakan (Phau et al. 2014). Yoon (2011) setuju bahwa pengaruh sosial menjadi pemicu dari pembajakan produk digital. Hal ini diperburuk dengan adanya persepsi bahwa melakukan pembajakan adalah hal yang biasa dan sudah umum dilakukan oleh orang pada umumnya. Individu menerima pengaruh sosial tanpa mempertimbangkan bahwa perilaku 
pembajakan adalah termasuk perbuatan kriminal walaupun tidak menyakitkan fisik sehingga muncul justifikasi yang mendasari untuk melakukan pembajakan. Seperti yang dijelaskan dalam neutralization theory bahwa perilaku yang dianggap salah akan dijustifikasi dan dirasionalisasikan ke dalam perilaku yang normal (Chatzidakis et al. 2004). Subjective norm dalam TPB dijelaskan sebagai pengaruh dari individu atau kelompok yang menjadi referensi untuk memunculkan perilaku tertentu (Ajzen 1991). Oleh karena itu, justifikasi dan rasionalisasi pembajakan akan ditampilkan dengan baik apabila yang memberikan pengaruh untuk melakukan pembajakan adalah individu atau kelompok yang menjadi referensinya.

Maraknya pembajakan di Indonesia memunculkan suatu pertanyaan terkait moral dari para konsumen. Apakah konsumen tidak mempertimbangkan moral dan konsekuensi atas pembajakan yang telah dilakukannya. Penelitian ini menemukan bahwa moral bukanlah sebagai bahan pertimbangan sebelum melakukan pembajakan. Konsumen di Indonesia cenderung untuk tetap melakukan pembajakan walaupun mereka mengetahui bahwa pembajakan adalah perbuatan yang keliru. Hasil penelitian ini berlawanan dengan Phau et al. (2014) dan Yoon (2011) yang menjelasakan bahwa individu yang dihadapkan pada dilema moral akan menghindari pembajakan. Hasil penelitian ini mendukung apa yang disebutkan oleh Swinyard, Rinne, dan Keng Kau (1990) bahwa orang Asia (termasuk Indonesia) sangat jarang mempertimbangkan moral dan tidak mempertimbangkan dampak negatif dari pembajakan. Tidak mengejutkan ketika Arli dan Tjiptono (2016) dengan sampel orang Indonesia menemukan bahwa konsumen Indonesia tidak takut terhadap konsekuensi atas pelanggaran hak cipta yang telah dilakukannya. Higgins (2007) dengan menggunakan self-control theory menjelaskan bahwa lemahnya pengendalian diri seseorang memungkinkan untuk melakukan perilaku pembajakan. Tidak adanya pengawasan dan sosialisasi terkait dengan pembajakan membuat moral tidak terbangun sehingga pengendalian diri untuk tidak membajak semakin rendah. Indonesia telah diperingatkan bahwa pelaksanaan hukum hak cipta (Undang-undang No 19 Tahun 2002) belum dilakukan dengan baik. Dampaknya, tidak ada suatu model yang memperlihatkan ketegasan hokum terhadap pembajakan. Mungkin saja orang Indonesia berfikir bahwa menjual produk bajakan adalah ilegal dan melanggar hukum, tetapi tidak untuk membeli produk bajakan (Arli dan Tjiptono 2016).

Banyaknya jumlah pembajakan juga dipengaruhi oleh harga yang mahal dari suatu produk digital. Harga menjadi isu yang penting bahkan menjadi isu utama mendasari perilaku pembajakan. Saat ini harga dari suatu produk digital asli dihargai sangat mahal dan bahkan tidak dapat diterima. Konsumen tidak mau untuk mengorbankan hartanya lebih besar untuk mendapatkan produk digital asli (Jackman danTorde 2014). Individu dengan pendapatan yang rendah tidak dapat membeli produk digital asli sehingga penggandaan ilegal, dan mengunduh dari internet yang tidak terotorisasi menjadi jalan akhir untuk mendapatkan produk tersebut. Dengan mengorbankan sedikit biaya sudah mampu untuk memperoleh 
produk bajakan yang memiliki manfaat sama dengan aslinya (Asongu 2014). Carmen, Carmen, dan Javier (2014) menyebutkan bahwa sedikit orang yang menerima harga untuk membayar untuk produk digital dengan cenderung untuk membajak. Penelitian ini mendukung argumen tersebut bahwa terdapat penerimaan harga yang rendah oleh konsumen sehingga akan lebih tertarik untuk melakukan pembajakan. Lau (2006) menemukan indikasi bahwa harga dari produk digital mahal dan sulit diterima (khususnya software). Pertanyaan saat ini ditujukan kepada perusahaan, mengapa harga produk digital asli sangat mahal. Terdapat kecenderungan bahwa perusahaan ingin mengejar profit terbukti dengan adanya potongan harga jika membeli dengan jumlah besar (Lau 2006). Kebijakan harga tersebut secara tidak langsung akan berakibat pada perusahaan itu sendiri karena akan memicu perilaku pembajakan demi memperoleh produk tersebut. Terlebih untuk konsumen dari mahasiswa akan sangat sulit sekali menerima harga yang sangat mahal untuk satu produk digital asli.

Niat untuk melakukan suatu perilaku pada dasarnya dipengaruhi oleh variabel-variabel yang mempengaruhinya. Dalam literatur terkait TPB dan TAM disebutkan bahwa jika individu sudah memiliki niat maka akan dilanjutkan menjadi perilaku nyata (Ajzen 1991; Venkatesh dan Bala 2008; Venkatesh 2000; Venkatesh et al. 2003). Penelitian ini menemukan bahwa perilaku pembajakan yang nyata didasari oleh adanya niat untuk melakukan pembajakan. Hasil yang sama dibuktikan oleh penelitian-penelitian di area pembajakan produk digital (Yoon 2011; Phau et al. 2014; Jackman dan Torde 2014).

\section{KESIMPULAN}

Perkembangan teknologi yang pesat membawa dampak baik positif maupun negatif. Di sisi positif teknologi mampu untuk membantu dan meningkatkan performa individu. Namun di sisi negatif, teknologi dapat digunakan untuk perilaku kriminal seperti pembajakan digital. Perilaku pembajakan produk digital adalah isu yang kompleks dengan melibatkan berbagai teori untuk investigasi. Konsumen mungkin menyadari bahwa penggandaan, membagi, membeli, mengunggah/mengunduh produk berlisensi secara ilegal adalah pencurian yang secara umum tidak dianggap sebagai aksi kriminal (Balestrino 2008).

Hasil penelitian menunjukan bahwa persepsi manfaat produk digital yang sama dengan aslinya mendorong untuk memunculkan upaya membajak. Pengaruh sosial juga merupakan faktor pemicu untuk membajak karena individu merasa bahwa pembajakan sudah umum dilakukan oleh orang disekelilingnya. Sehingga terdapat justifikasi untuk membenarkan perilaku menyimpang tersebut. Penelitian ini juga menemukan bahwa penilaian moral bukanlah sebuah pencegah untuk melakukan pembajakan. Konsumen sudah sadar bahwa pembajakan adalah salah. Namun karena sudah banyak dilakukan dan tidak ada hukuman yang benar-benar diberikan ke pelaku, maka pembajakan dapat dilakukan kapan saja. Selain itu, faktor harga menjadi isu utama mengingat harga yang mahal dari suatu produk digital terlisensi. Individu 
tidak mau untuk mengorbankan harta yang banyak sehingga memilih untuk membajak atau membeli produk bajakan, terutama untuk individu dengan penghasilan rendah.

\section{Implikasi Penelitian}

Berdasarkan pada temuan penelitian ini, perusahaan dan pemerintah perlu usaha lebih untuk memberikan edukasi kepada masyarakat terkait dengan dampak dari pembajakan. Hal ini disebabkan karena moral dari individu sudah tidak lagi mampu sebagai pencegah pembajakan. Upaya peningkatan moral perlu diterapkan untuk meningkatkan kesadaran bahwa pembajakan adalah perilaku kriminal. Perusahaan perlu membuat jalan alternatif untuk menentukan harga yang dapat dijangkau oleh individu dengan penghasilan rendah sebagai respon untuk menghindari pembajakan atas produknya. Didasari pada fakta bahwa produk digital bajakan memiliki manfaat yang sama dengan aslinya. Pemerintah juga perlu untuk menerapkan sistem blokir website untuk web yang menyediakan konten bajakan dan memperkuat sistem hukum terhadap pelaku pembajakan.

\section{Keterbatasan dan Saran}

Meskipun peneltian ini sudah menjelaskan faktor pendorong perilaku pembajakan, penelitian ini tidak menginvestigasi perilaku pembajakan dilihat dari gender, usia, pengalaman, dan kondisi yang memfasilitasi. Selain itu, tidak dibahasnya persepsi resiko mengingat bahwa produk bajakan bukanlah produk yang sesuai dan mungkin mengandung virus sehingga akan memberikan dampak bagi gadget maupun smartphone.

Penelitian selanjutnya diharapkan untuk menggunakan variasi usia dan tidak terfokus pada satu kelompok usia seperti dalam penelitian ini yang menggunakan sampel pada usia mahasiswa. Ruang lingkup penelitian yang menggunakan Yogyakarta mungkin masih kurang untuk merepresentasikan lingkup yang lebih luas. Penelitian ini juga tidak spesifik pada suatu produk digital (musik, film, dll) sehingga lebih baik untuk fokus pada satu produk digital tertentu. Hal yang menarik untuk diinvestigasi adalah mengapa individu sangat sulit untuk mengeluarkan harta untuk membeli produk digital asli atau terlisensi.

\section{DAFTAR PUSTAKA}

Ajzen, Icek. 1991. "The Theory of Planned Behavior." Organizational Behavior and Human Decision Processes 50: 179-211.

Altschuller, Shoshana., dan Raquel Benbunan-Fich. 2009. "Is Music Downloading the New Prohibition ? What Students Reveal through an Ethical Dilemma." Ethics and Information Technology 11 (1): 4956. 
Arli, Denni., dan Fandy Tjiptono. 2016. "Consumer Digital Piracy Behaviour among Youths: Insights from Indonesia.” Asia Pacific Journal of Marketing and Logistics 28 (5): 898-922.

Asongu, Simplice. 2014. "Software Piracy, Inequality and the Poor: Evidence from Africa." Journal of Economic Studies 41 (4): 526-53.

Balestrino, Alessandro. 2008. "It Is a Theft but Not a Crime." European Journal of Political Economy 24: 455-69.

Banerjee, Debasish., Timothy Paul Cronan, dan Thomas W. Jones. 1998. "Modeling IT Ethics : A Study in Situational Introduction." MIS Quarterly 22 (1): 31-60.

Bearden, William., Richard G. Netemeyer, dan Jesse E. Teel. 1989. "Measurement of Consumer Susceptibility to Interpersonal Influence" Journal of Consumer Research 15 (4): 473-81.

Beaumont, Jean-Francois, dan Cynthia Bocci. 2009. "A Practical Bootstrap Method for Testing Hypotheses from Survey Data.” Survey Methodology 35 (1): 25-35.

Business Software Alliances. 2010. "09 Piracy Study.” http://globalstudy.bsa.org/2009/ studies/globalpiracystudy2009.pdf. (diakses 29 Maret 2017).

Carmen, Camarero., Anton Carmen, dan Rodriguez Javier. 2014. "Technological and Ethical Antecedents of E-Book Piracy and Price Acceptance: Evidence from Spanish Case." The Electronic Library 32 (4): 542-66.

Chalkiti, Kalotina., dan Marianna Sigala. 2008. "Information Sharing and Idea Generation in Peer to Peer Online Communities : The Case of " DIALOGOI ." Journal of Vacation Marketing 14 (2): 12132. doi:10.1177/1356766707087520.

Chatzidakis, Andreas., Sally Hibbert, Darryn Mittusis, dan Andrew Smith. 2004. "Virtue in Consumption ?"Journal of Marketing Management 20: 527-44.

Cooper, Jan., dan Daniel Harrison. 2015. "The Social Organization of Audio Piracy on the Internet." Media, Culture \& Society 23: 71-89.

Cronan, Timothy Paul., dan Sulaiman Al-rafee. 2008. "Factors That Influence the Intention to Pirate Software and Media." Journal of Business Ethics 78: 527-45.

Davis, Fred. 1989. "Perceived Usefulness, Perceived Ease of Use, and User Acceptance of Information Technology." MIS Quarterly 13 (3): 319-40.

Davis, Fred., Richard Bagozzi, dan Paul Warshaw. 1989. "User Acceptance of Computer Technology : A Comparison Of Two Theoretical Models.” Management Science 35 (8): 982-1003.

- 1992. "Extrinsic and Intrinsic Motivation to Use Computers in the Workplace'." Journal of Apllied Social Psychology 22 (14): 1111-32.

Envisional. 2011. "Technical Report: An Estimate of Infringing Use of the Internet." http://documents.envisional.com/docs/Envisional-Internet_\%0AUsage-Jan2011.pdf. (diakses 27 Maret 2017).

Fishbein, Martin., dan Icek Ajzen. 1975. Beliefs, Attitude, Intention, and Behavior: An Introduction to Theory and Research. Reading: Addison-Wisley. 
Fornell, Claes., dan David Larcker. 1981. "Evaluating Structural Equation Models with Unobservable Variables and Measurement Error." Amerrican Marketing Association 18 (1): 39-50.

Gefen, David., Detmar Straub, dan Marie Claude Boudreau. 2000. "Structural Equation Modeling and Regression: Guidelines for Research Practice." Commucication of the Association for Information Systems 4 (1): 1-77.

Hair, Joseph., William Black, Barry Babin, Rolph Anderson, dan Ronald Tatham. 2010. Multivariate Data Analysis. New Jersey: Prantice Hall.

Hair, Joseph., Christian Ringle, dan Marko Sarstedt. 2011. "PLS-SEM: Indeed a Silver Bullet." The Journal of Marketing Theory and Practice 19 (2): 139-52.

Higgins, George. 2007. "Digital Piracy, Self-Control Theory, and Rational Choice : An Examination of the Role of Value." International Journal of Cyber Criminology 1 (1): 33-55.

Hinduja, Sameer. 2007. "Neutralization Theory and Online Software Piracy : An Empirical Analysis." Ethics and Information Technology 9: 187-204.

Jackman, Mahalia., dan Troy Torde. 2014. "Why Buy When We Can Pirate? The Role of Intentions and Willingness to Pay in Predicting Piracy Behavior." International Journal of Social Economics 41 (9): 801-19.

Kompas. 2016. "84 Persen Software Di Indonesia Adalah Bajakan." http://tekno.kompas.com/read/2016/07/21/11480047/84.persen.software.di.indonesia.adalah.bajakan. (diakses 10 Maret 2017).

Kumbhar, Rajendra. 2012. "E-Books: Review of Research and Writing during 2010." The Electronic Library 30 (6): 777-95.

Lau, Eric Kin-wai. 2006. "Factors Motivating People Toward Pirated Software." Qualitative Market Research: An International Journal 9 (4): 404-19.

Lysonski, Steven., dan Srinivas Durvasula. 2008. "Digital Piracy of MP3s : Consumer and Ethical Predispositions." Journal of Consumer Marketing 25 (3): 167-78.

Mccorkle, Denny., James Reardon, Douglas Dalenberg, Andrew Pryor, dan John Wicks. 2012. "Purchase or Pirate : A Model of Consumer Intellectual Property Theft." Journal of Marketing Theory and Practice 20 (1): 73-86.

McGuire, Brett. 2009. "Brett McGuire: Reasons We Buy Counterfeit Goods." http://jakartaglobe.id/archive/brett-mcguire-reasons-we-buy-counterfeit-goods/.

Morris, Robert., dan George Higgins. 2010. "Journal of Criminal Justice Criminological Theory in the Digital Age : The Case of Social Leaning Theory and Digital Piracy." Journal of Criminal Justice 38 (4): 470-80.

Phau, Ian., dan Johan Liang. 2012. "Downloading Digital Video Games: Predictors , Moderators and Consequences." Marketing Intelligence \& Planning 30 (7): 740-56.

Phau, Ian., Aaron Lim, Johan Liang, dan Michael Lwin. 2014. "Engaging in Digital Piracy of Movies: A Theory of Planned Behavior Approach." Internet Research 24 (2): 246-66.

Smith, Michael, dan Rahul Telang. 2010. "Piracy or Promotion ? The Impact of Broadband Internet 
Penetration on DVD Sales.” Information Economics and Policy 22 (4): 289-98.

Sudler, Hasshi. 2013. "Effectiveness of Anti-Piracy Technology : Finding Appropriate Solutions for Evolving Online Piracy.” Business Horizons 56 (2): 149-57.

Swinyard, Willian., Heikki Rinne, dan Ah Keng Kau. 1990. "The Morality of Software Piracy : A Cross Cultural Analysis.” Journal of Business Ethics 9: 654-64.

Tan, Benjamin. 2002. "Understanding Consumer Ethical Decision Making with Respect to Purchase of Pirated Software." Journal of Computer Assisted Learning 19 (2): 96-111.

Taylor, Steven. 2012. "Evaluating Digital Piracy Intentions on Behaviors." Journal of Services Marketing 26 (7): 472-83.

Tribun News, Tribun. 2014. "Tiap Bulan, Kerugian Pembajakan DVD Mencapai Rp 5 Triliun." http://www.tribunnews.com/bisnis/2014/11/02/tiap-bulan-kerugian-pembajakan-dvd-mencapai-rp-5triliun. (diakses 27 Maret 2017)

Vasileiou, Magdalini., Richard Hartley, dan Jennifer Rowley. 2009. “An Overview of the E-Book Marketplace." Online Information Review 33 (1): 173-92.

Venkatesh, Viswanath., dan Hillol Bala. 2008. "Technology Acceptance Model 3 and a Research Agenda on Interventions." Decision Sciences 39 (2): 273-315.

Venkatesh, Viswanath. 2000. "Determinants of Perceived Ease of Use : Integrating Control, Intrinsic Motivation , and Emotion into the Technology Acceptance Model." Information System Research 11 (4): $342-65$.

Venkatesh, Viswanath., Michael Morris, Gordon Davis, dan Fred Davis. 2003. "User Acceptance of Information Technology: Toward a Unified View.” MIS Quarterly 27 (3): 425-78.

Yoon, Cheolho. 2011. "Theory of Planned Behavior and Ethics Theory in Digital Piracy : An Integrated Model." Journal of Business Ethics 100: 405-17.

Zhang, Lixuan., Wayne Smith, dan William McDowell. 2009. “Examining Digital Piracy :"Information Resources Management Journal 22 (1): 24-44.

Zimerman, Martin. 2011. "E-Books and Piracy : Implications / Issues for Academic Libraries." New Library World 112 (1/2): 67-75.. 